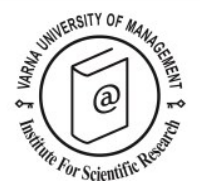

\title{
The roles of subjective vitality, involvement, experience quality, and satisfaction in tourists' behavioral intentions
}

\author{
Mustafa Cevdet Altunel ${ }^{1 *}$ and Ömer Erdem Koçak ${ }^{2}$
}

Received: 19/07/2016 Accepted: 04/11/2016

\footnotetext{
${ }^{1}$ Assistant Professor, Kırklarelı University, Kayalı Kampüsü, 39100, Kırklareli, Turkey. Phone: +90 28824615 32; E-mail: mustafacaltunel@gmail.com

2 Teaching fellow, Istanbul Medipol University, Fatih34083, İstanbul, Turkey. Phone: +90 44485 44; E-mail: kocak.omerdem@gmail.com

* Corresponding author
}

\begin{abstract}
This study provides and tests a model that examines the relationship between behavioral intentions and involvement, experience quality, satisfaction, and, as a personal resource, subjective vitality. Specifically, the study focuses on subjective vitality. Analyzing surveyed data from 408 cultural tourists, the results indicate that subjective vitality and involvement are the antecedents of experience quality. Given the results, theoretical and managerial implications are discussed.
\end{abstract}

(C) 2017 Varna University of Management. All rights reserved

Keywords: subjective vitality, involvement, experience quality, tourist experience, behavioral intentions, Istanbul.

Citation: Altunel, M., Ö. Koçak (2017) The roles of subjective vitality, involvement, experience quality, and satisfaction in tourists' behavioral intentions. European Journal of Tourism Research 16 , pp. 233-251

\section{Introduction}

Tourism organizations and destination authorities emphasize the quality of tourism experiences and tourism satisfaction to foster positive behavioral tourist intentions (Yuksel, 2000). Tourism satisfaction has received attention from tourism scholars and multiple studies that have demonstrated this concept as an antecedent of behavior intention (Chen, Huang, \& Petrick, 2016). For example, satisfied tourists are more likely to repurchase the product or recommend it to others (Chi \& $\mathrm{Qu}$, 2008; Gallarza \& Saura, 2006; Petrick, 2004).
Other studies assert that tourism satisfaction makes a significant contribution to overall life satisfaction (Chen, Huang, \& Petrick, 2016; Kim, Woo, \& Uysal, 2015) and subjective wellbeing (Chen, Lehto, \& Cai, 2013; McCabe \& Johnson, 2013; Sirgy, Kruger, Lee, \& Grace, 2011; Su, Swanson \& Chen, 2016). On the other hand, other studies concentrate on antecedents of satisfaction such as perceived value, perceived service quality, motivation, and destination image in order to determine how tourist satisfaction is achieved (Chi \& Qu, 2008; Devesa, Laguna, \& Palacios, 2010; 
Gallarza \& Saura, 2006; Petrick \& Backman, 2002; Yoon \& Uysal, 2005). Furthermore, recent studies have come up with a new concept, namely experience quality, which is now seen as more comprehensive than service quality (Altunel \& Erkut, 2015; Chen \& Chen, 2010).

In the tourism literature, when examining experience and/or service quality, and satisfaction, researchers are interested in the features of tourism (destinations, accommodations, transportation, etc.) rather than emphasizing personal resources. Therefore, in building experience quality and satisfaction, some personal resources (energy, attention, enthusiasm etc.) have been overlooked as antecedents. Other studies have investigated involvement (Goldsmith \& Emmert, 1991; Zaichkowsky, 1985) as it may be considered a personal resource and include personal interest and importance as a tourism subject. Meanwhile, other personal resources can be used to predict behavior. Personal resources are characteristics that are associated with an individual's ability to impact his/her environment successfully and those personal resources may effect individual motivations (Hobfoll, Johnson, Ennis \& Jackson, 2003). As a personal resource, energy has been operationalized in different ways. From Freud's concept of ego depletion to the idea of vitality, some concepts have been examined to clarify the availability of human energy. Among the concepts of personal energy (McNair, Lorr, \& Droppleman, 1971; Thayer, 1987, 1996; Watson \& Tellegen, 1985), vitality has been identified as a personal resource characterized by Ryan and Frederick as the energy available to one's self (1997), as in feelings of being alive, alert, and energized.

Accordingly, tourist vitality may be considered a determinant of cultural tourism, as such activities are generally believed to require energy (Martín-Ruiz, Castellanos-Verdugo, \& Oviedo-García, 2010). In tourist activities, such as visiting old towns, museums, and interacting with local people, the quality of the experience and its satisfaction may be influenced by a tourist's energy level. Tourists who feel vital are expected to have positive feelings and greater quality experiences, resulting in positive word- of-mouth in both the real and virtual world. If this is true, tourism organizations should pay special attention to the tourists' vitality at the time of the tourism and in the promotion of tourism products. This offers insights into why tourism firms should focus on customers with higher levels of vitality, thereby improving their efforts in achieving tourist satisfaction. Drawing on the broaden-and-build theory, a person's positive emotions may enhance his/her cognition and actions (Fredrickson, 2003). Thus, vitality may affect experience quality because it may increase an individual's feelings of learning and fun (Quinn, 2007).

In addition, vitality is seen as an indicator of well-being and life satisfaction (Ryan \& Frederick, 1997), referring to optimal psychological experience and functioning (Ryan \& Deci, 2001). In tourism, several studies exist that investigate the relationship between tourism satisfaction and life satisfaction. Most of these studies indicate that tourism activities affect a tourist's overall life satisfaction as well as the well-being of residents (Uysal, Sirgy, Woo, \& Kim, 2015). However, there is no empirical evidence that separately examines the impact of life satisfaction on tourism satisfaction and experience quality. Taking vitality into account as an indicator of well-being and life satisfaction, this relationship should be researched because well-being (having feelings of vitality) may affect experience quality. Therefore, it should be clarified whether or not positive and negative effects of vitality influence experience quality.

Therefore, the purposes of this research are to understand the effect of subjective vitality on experience quality and investigate the interrelationship between five major constructs: subjective vitality, involvement, experience quality, satisfaction, and behavioral intention. The results provide theoretical and practical information concerning the relationships between the variables.

\section{Conceptual background and hypotheses}

Subjective Vitality

For decades, the energy concept has been a perplexity within psychology. Freud's "economic model" emphasized energy as 
defense or resistance that can be depleted. Later, psychodynamic theorists agreed that energy could be lost or gained (Jung, 1960; Lifton, 1976; Perls, 1973). Generally, there is agreement that energy is depleted when there is psychological conflict and tension.

Energy is operationalized in different forms in psychology literature, although they all have somewhat similar meanings. However, in this study the concept of vitality is used (Ryan \& Frederick, 1997) rather than other concepts of subjective energy (Nix, Ryan, Manly \& Deci, 1999) such as vigor (Ryan \& Bernstein, 2010; Shirom, 2003), feeling alive (Christianson, Spreitzer, Sutcliffe, \& Grant, 2005), and zest (Miller \& Stiver, 1997).

Vitality comes from the Latin word vita (life), implying that one who is vital feels alive, full of energy, inspired, and enthusiastic. It is conceptualized as "a dynamic phenomenon, pertinent to both mental and physical aspects of functioning and thus refers to a person who is energetic, feeling alive, and fully functioning" (Ryan \& Bernstein, 2004, p. 274). It is an aspect of both eudaimonic and physical wellbeing (Salama-Younes, 2011). In short, vitality refers to feeling capable, energetic, and healthy. Psychologically and physically, vitality refers to the feeling of aliveness (Akin, 2012; Uysal, Satici \& Akin, 2013). This state of "aliveness" psychologically provides meaning and purpose to an individual's actions (Ryan \& Bernstein, 2004). It has also been described as creating an affective experience (Ryan \& Frederick, 1997) and positive energetic arousal (Thayer, 1989). It involves living with excitement, energy, enthusiasm, vigor, and not acting inconsistently.

Vitality has been referred to with different names in different cultures but with similar definitions. While ancient Japanese and Taoist cultures are known to have $\mathrm{Ki}$ and $\mathrm{Chi}$, and Jing concepts, respectively, they almost mean the same thing: being full of internal energy that can engender mental and physical health (Ryan \& Frederick, 1997).

Although, vitality is characterized as positive energy available to an individual (Nix et al., 1999), someone who is jittery, tense, or angry may be energized but not necessarily vital.
Ryan and Frederick (1997) found that negative affectivity with high arousal and subjective vitality are negatively associated. Negative energy, due to over-arousal, tenseness, or stimulants like caffeine, has been distinguished from vitality (Peterson \& Seligman, 2004; Thayer, 1996). Indeed, it has a more discrete affect than happiness and pleasure (Nix et al., 1999). According to the Circumplex Model of Affect by Russell (1980), vitality is a positive affecting emotion, characterized by a high level of arousal, and is distinct from other positive affecting emotions with lower arousal levels (relaxed, pleased, at ease, and satisfied).

Due to the subjective vitality concept reflecting organismic well-being, it should be changed by both psychological and physiological factors that affect energy including somatic factors like physical symptoms and perceived body functioning, diet, exercise, sleep patterns, and smoking (Rozanski et al., 2005). People, who have disabling chronic pain, demonstrate lower vitality. Personality traits and affective dispositions have also been found to be related (Ryan \& Frederick, 1997; Stewart, Hays, \& Ware, 1992). Physiologically, vitality is facilitated by health. Additionally, health-related stressors, especially those that represent potential threats to one's autonomy or control, are expected to negatively affect subjective vitality. Individuals vary in their experience of vitality as a function not only from physical influences (e.g., illness or fatigue), but also psychological factors (e.g., being in love, having a mission, being effective) (Ryan \& Frederick, 1997).

People usually enhance or repeat situations that increase their vitality, and try to avoid situations they perceive as decreasing their vitality (Collins, 1993). Vitality also encourages people to interpret events positively and expect positive events to reoccur (Arkes, Herren, \& Isen, 1988). Additionally, vitality affects the effort that people invest in activities, and reflects a person's well-being as well as how positive their experience is (Ryan \& Frederick, 1997).

Vital people may become more active, invest more physical resources, be more productive, cope better with stress and challenges, report greater mental health (Penninx et al., 2000), 
The roles of subjective vitality, involvement, experience quality, and satisfaction in tourists' behavioral intentions.

desire to feel excitement, and focus their attention (Ryan \& Frederick, 1997). Therefore, vitality is expected to foster experience quality because people who are vital are also expected to have more fun than others. Moreover, vitality is seen as a positive emotion. Examining the build-and-broaden theory of Frederickson (2000), vitality is a positive emotion enhancing people's ability to use cognitive skills such as learning. Because vital and cheerful people are more likely to be alert and fresh (Fini, Kavousian, Beigy, \& Emami, 2010), vital people may learn more compared to others. Vitality could be one determinant that influences experience quality via increased learning. It is known that these positive affects are contagious to others (Barsade, 2002; Bartel \& Saavedra, 2000; Totterdell, 2000), thus causing an increase in learning and fun at a group-level due to interactions between vital tourists and others in the group. Finally, according to Brown and Ryan (2004) and Ortner, Kilner, and Zelazo (2007) vitality influences mindfulness. This relationship has given us a clue which means vitality creates an active-living of the present situation and place. Therefore, by increasing a sense of presence, vitality may contribute to feeling of escape from daily routines, providing a powerful psychological detachment. It is believed that this mindfulness provides more presence in the moment and place for an individual who therefore is not thinking about other life issues.

Last but not least, it is thought to be a crucial experience quality factor for Istanbul's cultural tourism, as most of cultural places are located in old city in which cars and other vehicles are not reasonable to use. Thus, tourist generally go from one to other on foot within historical peninsula which is about $15 \mathrm{~km}^{2}$. Another issue is that Istanbul's crowdedness and number of cultural attractors may impede tourist's aliveness within visit days, tourist try to keep their attention and aliveness in order to maintain a high experience quality. Therefore, vitality concept, implying energy and aliveness, can help individuals to exert required effort and stay alert. Hence, it is proposed that:

H1. Subjective vitality positively influences experience quality of cultural tourists. Involvement
Involvement is defined as the degree of importance that a person gives to a phenomenon. Involvement is also a variable that is frequently used in consumer behavior studies since involvement affects attitudes toward an activity and decision-making (Josiam, Smeaton, \& Clements, 1999). Although there is no precise definition of involvement, from a marketing perspective, researchers define it as "a person's perceived relevance of the object based on inherent needs, values and interests" (Zaichkowsky, 1985). Involvement represents an individual's interest level, an object's degree of importance to the individual, and an individual's orientation to an object (Zaichkowsky, 1994). Customer involvement also refers to the process where the agent is the customer who acts with zest, enthusiasm, and interest (Goldsmith \& Emmert, 1991).

The introduction of the involvement concept in the leisure field occurred in the 1990s (Havitz \& Dimanche, 1999) and identified tourism involvement as a factor that may influence tourists' decision-making process (Gursoy \& Gavcar, 2003; Hochgraefe, Faulk, \& Vieregge, 2012). Tourism researchers define involvement as a degree of interest in an activity and the affective response associated with that interest (Manfredo, 1989). Involvement is also defined as "the state of identification existing between an individual and a recreational activity, at one point in time, characterized by some level of enjoyment and self-expression being achieved through the activity" in a recreational context (Selin \& Howard, 1988, p. 237). In this study, the visitor's involvement is conceptualized as per Goldsmith and Emmert (1991). Therefore, involvement is seen as a remarkable variable in leisure behavior as involved individuals planning leisure travel will pay more attention to relevant travel information (Reid \& Crompton, 1993).

Many scales have been developed to operationalize the involvement construct (Havitz \& Dimanche, 1999; Rothschild, 1984), but only two have attracted attention and have been tested by other researchers. These are Zaichkowsky's (1985) "personal involvement inventory (PII)" and Laurent and Kapferer's (1985) "customer involvement profile (CIP)." 
While the CIP involves five constructs (importance, pleasure, sign, risk probability, and risk consequence), IIP is a bipolar adjective scale.

Several studies have been conducted that include a causal relationship between involvement, experience quality, and satisfaction. In particular, contradictory study results have drawn attention to the relationship between involvement and satisfaction. While some researchers suggest a positive and significant influence (Kim, Woo, \& Uysal, 2015; Lu, Chi, \& Liu, 2015), others reject the relationship (Chiu, Lee, \& Chen, 2014). This conflict arises from the context used in the research. On the other hand, the relationship between involvement and experience quality is seldom considered. However, in a recent study, Altunel and Erkut (2015) found involvement to have a significant and positive influence on experience quality. Hence, it is proposed that:

H2. Involvement positively influences experience quality of cultural tourists.

H3. Involvement positively influences satisfaction of cultural tourists.

\section{Experience quality}

In much of the marketing literature, servicedominant logic has replaced the goodscentered view (Vargo \& Lusch, 2004) and scholars are currently focusing on how the customer experience may stretch beyond the service itself (Klaus \& Maklan, 2012). It is expostulated that the overall quality of a service experience cannot be determined solely by the results of SERVQUAL, the scale of servicedominant logic (Fick \& Ritchie, 1991). Furthermore, experience quality is different from service quality in some aspects. For example, measuring experience quality is idiosyncratic; the evaluation appears to be holistic/gestalt; the scope more general; the structure of its benefit experiential/ hedonic/symbolic; and the psychological result emotional (Otto \& Ritchie, 1996).

From the tourism perspective, service quality connects with the excellence of the service under the control of the supplier; experience quality on the other hand refers to a more general concept because of the personal interpretation of the visitor. This term also covers the attributes provided by the supplier and is analyzed as 'tourists' affective responses to their desired social-psychological benefit" (Chen \& Chen, 2010).

Although the emotional nature of experience quality is emphasized, the evaluation of the experience does not only focus on emotions (Chang \& Horng, 2010). In another study, "the customer experience originates from a set of interactions between a customer and a product, a company, or part of its organization, which provoke a reaction. This experience is strictly personal and implies the customer's involvement at different levels (rational, emotional, sensorial, physical, and spiritual)" (Gentile, Spiller, \& Noci, 2007, p. 397).

Looking at it from the tourism point of view, the tourist experience is said to be "a consistent flow of thoughts and feelings during moments of consciousness which occur through highly complex psychological, sociological, and cognitive interaction processes" (Kang \& Gratzel, 2012, p. 442). Therefore, cognition is also a part of experience quality. In this study, experience quality concerning tourism is conceptualized as a "constant flow of thoughts and feelings during moments of consciousness that occur through highly complex psychologycal, sociological, and cognitive interaction processes as tourists participate in consumption activities and interact with the service surroundings, service providers, other customers, customers' companions, and other elements in the destination" (Altunel \& Erkut, 2015).

Otto and Richie's (1996) experience quality scale consists of four dimensions: hedonics, peace of mind, involvement, and recognition. Kao, Huang, and $\mathrm{Wu}$ (2008) also examined it in four dimensions (immersion, surprise, participation, and fun). Chang and Horng (2010) stated that quality of experience is made up of five dimensions: physical surroundings, service providers, other customers, customer's companions, and the customers themselves. Kang and Gretzel (2012) and Altunel and Erkut (2015) analyzed tourist experiences in three dimensions: learning, enjoyment, and escape. The effect of service quality on satisfaction and behavioral intentions are well studied in 
The roles of subjective vitality, involvement, experience quality, and satisfaction in tourists' behavioral intentions.

literature (Hui, Wan, \& Cheng, 2010; Lee \& Beeler, 2006; Parasuraman, Zeithaml, \& Malhotra, 2005). Service quality studies still dominate the marketing and tourism literature, however, in recent years, the number of researchers examining the experience side is increasing (Altunel \& Erkut, 2015; Chen \& Chen, 2010; Cole \& Scott, 2004; Kang \& Gretzel, 2012; Kao, Huang, \& Wu 2008; Zins, 2002). The positive effect of experience quality on satisfaction and behavioral intentions seems justified by the results of past studies. Hence, it is proposed that:

H4. Experience quality positively influences the satisfaction of cultural tourists.

H5. Experience quality positively influences behavioral intentions of cultural tourists.

\section{Satisfaction}

A vital issue for any firm's marketing activities is the concept of satisfaction (Machleit \& Mantel, 2001). High levels of customer satisfaction are thought to engender customer loyalty, reduce price elasticity, lower future transaction costs, attract new customers, and minimize competition risk (Anderson, Fornell, \& Lehmann, 1994). In service industries, such as tourism, managing customer satisfaction becomes critical for survival, development, and success (Sirakaya, Petrick, \& Choi, 2004). It is said that satisfied tourists will revisit the areas or advise others to; dissatisfied ones may share undesired comments externally. Negative comments are detrimental to both business success and a destination's market reputation (Chen \& Chen, 2010; Reisinger \& Turner, 2003).

Satisfaction is defined as "the consumer's fulfillment response" and "a judgment that a product or service feature, or the product or service itself, provides a pleasurable level of consumption-related fulfillment" (Oliver, 1997, p. 13). Additionally, there may be a gap between pre-consumption expectation and perceived post-consumption performance. From the tourism point of view, when a tourist's level of fulfillment and enjoyment is above prior expectations, satisfaction occurs.

Dissatisfaction is when the opposite occurs (Chen \& Chen, 2010).
The operationalization of customer satisfaction has been done in different ways, as there is a considerable amount of debate around the meaning and application of the term (Zeithaml, Bitner, \& Gremler, 2013). At least, two approaches to satisfaction exist (Ekinci, Dawes, \& Massey, 2008; Nam, Ekinci, \& Whyatt, 2011): transient (transaction-specific) and overall satisfaction. Transient satisfaction stems from activity and behavior evaluations, which occur while interacting with the service (Oliver, 1997). Accordingly, transient satisfaction should be captured right after the customer interaction with the service (e.g., satisfaction with a food) (Nam et al., 2011).

On the other hand, overall satisfaction is based on all of the interactions with the service provider (Ekinci et al., 2008; Nam et al., 2011). While transient satisfaction may vary from experience to experience, overall satisfaction is generally, relatively stable and reflects overall purchasing attitude towards a brand (Eid \& ElGohary, 2015). According to Anderson and Fornell (1994), most satisfaction research uses overall satisfaction for predicting a customer's behavioral intentions and a firm's past, present, and future performances due to its underlying structure and usefulness.

Because satisfaction relates to positive postpurchase behaviors and the overall success of a destination, tourist satisfaction has become an interesting topic in literature (Baker \& Crompton, 2000; Yoon \& Uysal, 2005). In particular, satisfaction has been previously identified as a predictive factor of destination and event loyalty (Akhoondnejad, 2016; Chi \& Qu, 2008; McDowall, 2010; Sun, Chi, \& Xu, 2013), revisit or repurchase intention (Alegre \& Garau, 2010; Prayag, 2009; Rittichainuwat, Qu, \& Mongknonvanit, 2002), and positive word-ofmouth (Prebensen, Skallerud, \& Chen, 2010; Wang \& Hsu, 2010; Williams \& Soutar, 2009). Thus, it is proposed that:

H6. Satisfaction positively influences behavioral intentions of cultural tourists.

\section{Behavioral intentions}

For marketing strategists, achieving satisfaction was a bigger goal in the 1970s and 1980s. Today, there is some belief that performance can be better predicted by behavioral intentions 
(Chi \& Qu, 2008) associated with a service provider's ability to get customers to: (1) make positive comments (2) recommend services to others, (3) remain loyal, (4) spend more with the firm, and (5) pay price premiums (Zeithaml, Berry, \& Parasuraman, 1996).

Loyalty is described by Oliver (1999) as a strong commitment to repurchase or repatronize a preferred product/service consistently in the future, hence causing repetitive same-brand purchasing, regardless of situational factors and marketing efforts by other product/services. Another study also crystalized loyalty as the relationship strength between relative attitude and the repeated patronage of individuals (Dick \& Basu, 1994).

A unique definition of the customer loyalty concept does not yet exist. In literature, it is conceptualized in three ways (Uncles, Dowling, \& Hammond, 2003): (1) attitudinal loyalty to the brand, (2) behavioral loyalty, and (3) codeterminants of brand purchases. From a behavioral perspective, observing purchasing behavior can provide a measurement of loyalty. From an attitudinal perspective, loyalty is indirectly measured via the attitude or intention to repeat the purchase (Hernandez-Lobato et al., 2006). Likewise, from a cognitive perspective (i.e., when the consumer receives information), an affective phase (i.e., an attitude of liking the brand), conative stage (i.e., behavioral intention), and action control of loyalty (i.e., behavioral consistency of repurchase) are argued (Lee, Graefe, \& Burns
2007). In this manner, indirectly measured loyalty in the conative stage may refer to behavioral intention. Loyalty in tourism literature demonstrates a tourist's willingness to recommend the destination to others and intention to revisit (Opperman, 2000). Figure 1 shows this proposed conceptual model.

\section{Method}

A self-administered questionnaire survey was conducted to collect data from cultural tourists visiting Sultanahmet district in Istanbul. The questionnaire included sections about demographic information, involvement, vitality, experience quality, satisfaction, and behavioral intentions. Demographic questions are located in section 1. In section 2, involvement is measured with eight items derived from a previous study (Wirtz, 2003). In section 3, vitality is measured with six items derived from a previous study (Ryan \& Frederick, 2007). In section 4 , experience quality is measured with nine items derived from a previous study (Kang \& Gratzel, 2012). In section 5, satisfaction is measured with three items derived from previous studies (Chen \& Chen, 2010; Kang \& Gratzel, 2012). Finally, in section six behavioral intentions are measured with four items derived from previous studies (Chen \& Chen, 2010; Kao, Huang, \& Wu 2008). All the items except demographic variables are measured using a seven-point Likert-type scale from "totally disagree (1)" to "totally agree (7)."

Partial least squares (PLS) was performed using the statistical software package

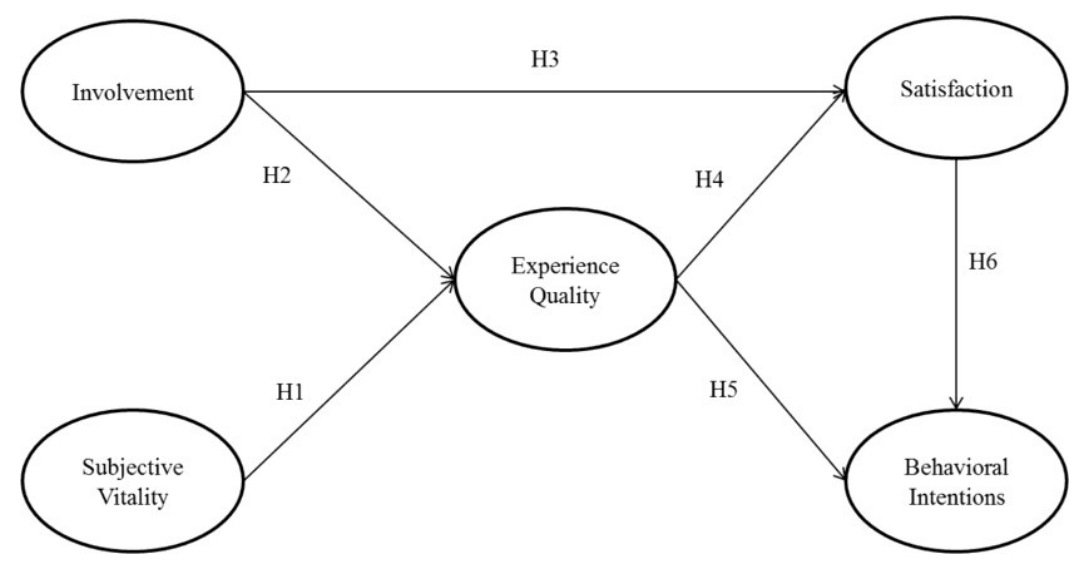

Figure 1. Conceptual Model 
SmartPLS 3 (Ringle, Wende, \& Becker, 2015) to analyze the scale accuracy and structural model. The PLS method is a variance-based structural equation modeling for causalpredictive analysis (Henseler, Ringle, \& Sinkovics, 2009) and unlike traditional structural equation modeling, it does not generate an overall test statistic, such as the $\mathrm{x} 2$ goodness-of-fit (Rigdon, 2005). It is a soft modeling technique proposing "soft" distributional assumptions (Vinzi et al., 2010) and it is considered a powerful tool because of its ability to cope with small sample sizes (Bontis, 1998).

To test the coefficient significance of the path modeling, the bootstrapping method was applied. The measurement model is composed of 7 latent constructs and 30 observed variables. Experience quality, the second-order latent construct, was combined with three latent variables, learning, enjoyment, and escape to form one measure of experience quality.

The survey was conducted in Sultanahmet district during June and September 2015. Sultanahmet (located in historical Old Istanbul) contains tourist sites such as the Hagia Sophia,
Topkapi Palace, Hagia Irene, Great Palace Mosaic museum, Istanbul archaeological museums, The Blue Mosque, Basilica Cistern, the Turkish and Islamic Art Museum, the Byzantine Hippodrome, and the Spice Bazaar, which are visited by the majority of cultural tourists in Istanbul (Tonguç \& Yale, 2010; Yenen, 2013). During face-to-face interactions, data was collected by trained assistants in the center of Sultanahmet. The survey was conducted on different days in different spots between $11 \mathrm{am}$ and $9 \mathrm{pm}$. Respondents were selected randomly. Visitors who can speak English and had visited at least two of the tourist sites in the Sultanahmet district were asked whether they had free time to complete the questionnaire. A total of 450 questionnaires were collected, and 408 usable responses were obtained due to incomplete surveys.

In the visitors' profile, $49.8 \%$ were female. The age distribution of the sample was as follow: under 20 (10\%), 20-29 (23\%), 30-39 (21.6\%), $40-49(18.6 \%), 50-59(23.5 \%)$ and 60 or more (3.2\%). Approximately \% 67 of the sample held a university or postgraduate degree. The visitors who were student accounted for 23.3 $\%$, employed individuals for $25.7 \%$, employers

Table 1. Demographic profile of respondents

\begin{tabular}{|c|c|c|c|c|c|}
\hline \multicolumn{3}{|l|}{ Gender } & \multicolumn{3}{|c|}{ Marital Status } \\
\hline & $\mathbf{N}$ & $\%$ & & $\mathbf{N}$ & $\%$ \\
\hline Female & 203 & 49,8 & Married & 204 & 50 \\
\hline Male & 205 & 50,2 & Single & 204 & 50 \\
\hline Total & 408 & 100,0 & Total & 408 & 100 \\
\hline \multicolumn{3}{|l|}{ Education } & \multicolumn{3}{|c|}{ Age } \\
\hline & $\mathbf{N}$ & $\%$ & & $\mathbf{N}$ & $\%$ \\
\hline No formal education & 8 & 2,0 & Under 20 & 41 & 10 \\
\hline \multicolumn{6}{|l|}{ School } \\
\hline Secondary / High School & 122 & 29,9 & $30--39$ & 88 & 21,6 \\
\hline College / University & 224 & 54,9 & $40-49$ & 76 & 18,6 \\
\hline Postgraduate & 47 & 11,5 & $50-59$ & 96 & 23,5 \\
\hline \multirow[t]{2}{*}{ Total } & 408 & 100 & 60 and older & 13 & 3,2 \\
\hline & & & Total & 408 & 100 \\
\hline \multicolumn{3}{|c|}{ Occupation } & \multicolumn{3}{|c|}{ Income } \\
\hline \multirow{8}{*}{$\begin{array}{l}\text { Employer } \\
\text { Employee } \\
\text { Retired } \\
\text { Student } \\
\text { Not working } \\
\text { Total }\end{array}$} & $\mathbf{N}$ & $\%$ & & $\mathbf{N}$ & $\%$ \\
\hline & 63 & 15,4 & Less than $\$ 1000$ & 50 & 12,3 \\
\hline & 105 & 25,7 & $1001-3000 \$$ & 144 & 35,3 \\
\hline & 63 & 15,4 & $3001-6000 \$$ & 109 & 26,7 \\
\hline & 95 & 23,3 & $6001-9000 \$$ & 28 & 6,9 \\
\hline & 82 & 20,1 & $9001 \$$ or more & 15 & 3,7 \\
\hline & 408 & 100 & No regular income & 62 & 15,2 \\
\hline & & & Total & 408 & 100 \\
\hline
\end{tabular}


for $15.4 \%$, not working individuals for $20.1 \%$ and retired for $15.4 \%$. The majority of the sample had a monthly income of 1001-3000 USD $(35.3 \%)$. The demographic profile of the respondents is presented in the Table 1.

\section{Empirical results}

Measurement model

Reliability and construct validity scores were examined to ensure the appropriateness of the research instrument before testing the hypotheses. The internal consistency for reliability of the measurement models was tested using Cronbach's alpha and Fornell's composite reliability (Fornell \& Larcker, 1981). Each construct should have Cronbach's a values above the recommended lower limit of 0.6 (Nunnally \& Bernstein, 1994), and CR indexes should be greater than 0.8 (Werts, Linn, \& Jöreskog, 1974), to support construct reliability.

Convergent and discriminant validity were examined to test construct validity (Chin, Gopal, \& Salisbury, 1997). Convergent validity is the measure of constructs that, theoretically, should be related to each other (Kim, 2012) and was assessed by examining the item loadings and their associated t-values and AVE values of the constructs. All of the indicators must be greater than 0.50 (Wixom \& Watson, 2001) and constructs had AVE values above the lower limit of 0.5 (Fornell \& Larcker, 1981), indicating that convergent validity has been achieved. Discriminant validity refers to the degree of specific construct, which is different to other constructs, and AVE can be used for evaluating discriminant validity. The square root of the AVE should be greater than any of the inter-construct correlations (Fornell \& Larcker, 1981; Hair et al., 2013). Convergent validity and discriminant validity work together as subtypes of construct validity, and neither measure alone is sufficient for establishing construct validity (Chin, 1998).

Because of a low t-value and standardized loadings, 3 questions in the vitality scale and 1 question in the experience quality scale were deleted and other constructs were reanalyzed. Table 2 shows factor loadings, t-values, Cronbach's alpha, Fornell's composite reliability scores, and AVE and indicates adequate internal consistency and convergent validity.

Table 3 presents the square root of the AVE of the constructs compared to the correlations. According to the results, discriminant validity is achieved.

\section{Structural model and hypothesis testing}

The structural model was evaluated using standardized path coefficients, their significance level (t-statistic), and $\mathrm{R}^{2}$ estimates. Figure 2 provides details on the parameter estimates for the model and Table 3 reports the results of the hypotheses tests. The $R^{2} s$ of experience quality, satisfaction, and behavioral intentions are respectively $0.31,0.36$ and 0.36 respectively, which indicate that the exogenous variable of each construct explains $31 \%, 36 \%$, and $\% 36$ of the variance of each construct, approximately. $\mathrm{R}^{2}$ values are greater than the recommended value of 0.10 (Falk \& Miller, 1992).

Five of six hypotheses including the direct paths between variables are supported according to the statistical results. $\mathrm{H} 1$ and $\mathrm{H} 2$ predict that a high level of vitality and involvement have a direct positive effect on experience quality. The analysis results support $\mathrm{H} 1$ and $\mathrm{H} 2$ because a positive and statistically significant relationship was found $(\beta=0.20, p<$ $0.001 / \beta=0.46, p<0.001)$. H3 predicts that involvement has a direct positive effect on satisfaction. This hypothesis is rejected due to the insignificant effect $(\beta=0.05, p>0.05)$. H4 and $\mathrm{H} 5$ predict that a level of experience quality has a direct positive effect on satisfaction and behavioral intention. The analysis result supports $\mathrm{H} 4$ and $\mathrm{H} 5$ because a positive and statistically significant relationship was found $(\beta$ $=0.57, p<0.001 ; \beta=0.26, p<0.001)$. Finally, hypothesis 6 predicts that a high level of satisfaction has a direct positive effect on behavioral intention. The result supports $\mathrm{H} 6$ because a positive and statistically significant relationship was found $(\beta=0.41, p<0.001)$. Table 4 presents the results of the hypotheses tests. 
The roles of subjective vitality, involvement, experience quality, and satisfaction in tourists' behavioral intentions.

Table 2. Reliability and Convergent Validity of the Constructs

\begin{tabular}{|c|c|c|c|c|c|}
\hline Construct and Indicators & $\begin{array}{l}\text { Factor } \\
\text { Loading }\end{array}$ & $\begin{array}{l}\mathrm{t}- \\
\text { value }\end{array}$ & $\begin{array}{l}\text { Cronbach's } \\
\text { Alpha }\end{array}$ & $\begin{array}{l}\text { Composite } \\
\text { Reliability }\end{array}$ & $\begin{array}{l}\text { Average } \\
\text { Variance } \\
\text { Extracted }\end{array}$ \\
\hline $\begin{array}{l}\text { First-order } \\
\text { Involvement }\end{array}$ & & & 0.90 & 0.92 & 0.59 \\
\hline Cultural tourism matters to me. & 0.715 & 17.8 & & & \\
\hline Cultural tourism means a lot to me. & 0.814 & 30.4 & & & \\
\hline Cultural tourism is important to me. & 0.786 & 31.0 & & & \\
\hline Cultural tourism is relevant to me. & 0.812 & 39.3 & & & \\
\hline In general, I think that cultural tourism is a lot of fun. & 0.757 & 29.2 & & & \\
\hline In general, I think that cultural tourism is interesting. & 0.726 & 21.5 & & & \\
\hline In general, I think that cultural tourism is neat. & 0.775 & 34.5 & & & \\
\hline In general, I think that cultural tourism is appealing. & 0.749 & 23.2 & & & \\
\hline Vitality & & & 0.76 & 0.86 & 0.67 \\
\hline Sometimes I am so alive I just want to burst. & 0.889 & 45.5 & & & \\
\hline I have energy and sprit. & 0.771 & 17.2 & & & \\
\hline I nearly always feel awake and alert. & 0.782 & 20.2 & & & \\
\hline Learning & & & 0.85 & 0.91 & 0.77 \\
\hline $\begin{array}{l}\text { I expanded my understanding of Sultanahmet } \\
\text { destination. }\end{array}$ & 0.835 & 37.0 & & & \\
\hline I gained information and knowledge about Sultanahmet. & 0.909 & 85.3 & & & \\
\hline I learned many different things about Sultanahmet. & 0.881 & 61.8 & & & \\
\hline Enjoyment & & & 0.76 & 0.86 & 0.68 \\
\hline I had fun. & 0.834 & 40.6 & & & \\
\hline I enjoyed being in Sultanahmet. & 0.820 & 48.4 & & & \\
\hline I derived a lot of pleasure from the visit of Sultanahmet. & 0.819 & 39.5 & & & \\
\hline Escape & & & 0.84 & 0.93 & 0.86 \\
\hline I got away from it all. & 0.923 & 76.8 & & & \\
\hline I got so involved that I forgot everything else. & 0.935 & 113.0 & & & \\
\hline Satisfaction & & & 0.82 & 0.90 & 0.75 \\
\hline Overall, Sultanahmet is satisfactory. & 0.888 & 71.0 & & & \\
\hline The atmosphere of Sultanahmet is satisfactory. & 0.880 & 52.8 & & & \\
\hline $\begin{array}{l}\text { The historical relic authenticity of Sultanahmet is } \\
\text { satisfactory. }\end{array}$ & 0.820 & 30.2 & & & \\
\hline Behavioral intention & & & 0.88 & 0.92 & 0.73 \\
\hline If I could, I would revisit this destination again. & 0.861 & 38.3 & & & \\
\hline $\begin{array}{l}\text { I will speak highly of Sultanahmet destination to my } \\
\text { friends and relatives. }\end{array}$ & 0.872 & 38.7 & & & \\
\hline $\begin{array}{l}\text { I always say positive things about Sultanahmet } \\
\text { destination to other people. }\end{array}$ & 0.866 & 42.6 & & & \\
\hline $\begin{array}{l}\text { I would recommend Sultanahmet destination to other } \\
\text { people. } \\
\text { Second-order }\end{array}$ & 0.815 & 34.3 & & & \\
\hline Experience quality & & & 0.84 & 0.88 & 0.59 \\
\hline Learning & 0.787 & 27.9 & & & \\
\hline Enjoyment & 0.801 & 36.7 & & & \\
\hline Escape & 0.719 & 17.4 & & & \\
\hline
\end{tabular}

Table 3. Discriminant Validity

\begin{tabular}{llllllll} 
& 1 & 2 & 3 & 4 & 5 & 6 & 7 \\
\hline Behavioral intention & $\mathbf{0 . 8 5}$ & & & & & & \\
Involvement & 0.21 & $\mathbf{0 . 7 7}$ & & & & & \\
Vitality & 0.08 & 0.35 & $\mathbf{0 . 8 1}$ & & & & \\
Escape & 0.41 & 0.39 & 0.37 & $\mathbf{0 . 9 3}$ & & & \\
Enjoyment & 0.41 & 0.42 & 0.26 & 0.40 & $\mathbf{0 . 8 2}$ & & \\
Learning & 0.27 & 0.40 & 0.24 & 0.33 & 0.47 & $\mathbf{0 . 8 8}$ & \\
Satisfaction & 0.56 & 0.35 & 0.09 & 0.41 & 0.46 & 0.50 & $\mathbf{0 . 8 6}$ \\
\hline
\end{tabular}

${ }^{\mathrm{a}} \mathrm{p}<0.001,{ }^{\mathrm{b}}$ not significant/

Note: 5,000 samples bootstrapping procedure used 


\section{Discussion and conclusions}

Theoretical implications

The main purpose of this research was to examine the effect of subjective vitality on experience quality and investigate the interrelationship between subjective vitality, involvement, experience quality, satisfaction, and behavioral intentions. Although there is increased attention on the concept of subjective well-being among tourism researchers (Dolnicar et al., 2012; Gilbert \& Abdullah, 2004; Sirgy et al., 2011) and the antecedents of tourists' subjective well-being have been explored (Su et al., 2016), the effect of subjective well-being (specifically vitality) on experience quality has not yet been examined.

The major finding of this study is that subjective vitality has a positive effect on experience quality. This reveals that subjective vitality is a critical resource. As stated similarly in existing literature, vitality is found to engender feelings of fun and escapism(Ryan and Frederick, 1997; Brown and Ryan, 2004) as well as enhance learning capacity (Frederickson, 2000), all of which increases experience quality.

The relationships between involvement, experience quality, and satisfaction were investigated by a previous study (Altunel \& Erkut, 2015). In this study, positive and significant relationships were found between involvement and experience quality and involvement and satisfaction. A relatively low beta coefficient between involvement and satisfaction may be a clue to the mediating role of experience quality. Similarly, in our study a positive and significant effect of involvement on experience quality and experience quality on satisfaction were found. However, an insignificant effect of involvement on satisfaction was found, therefore, it can be

Table 4. Hypotheses Tests

\begin{tabular}{llll}
\hline Research hypothesis & $\begin{array}{l}\text { Path } \\
\text { Coefficient }\end{array}$ & $\begin{array}{l}\text { t- } \\
\text { value }\end{array}$ & Results \\
\hline H1-Vitality $\rightarrow$ Experience quality & 0.20 & $3.57^{\mathrm{a}}$ & Supported \\
H2-Involvement $\rightarrow$ Experience quality & 0.46 & $8.89^{\mathrm{a}}$ & Supported \\
H3-Involvement $\rightarrow$ Satisfaction & 0.05 & $0.98^{\mathrm{b}}$ & Rejected \\
H4-Experience quality $\rightarrow$ Satisfaction & 0.57 & $11.1^{\mathrm{a}}$ & Supported \\
H5-Experience quality $\rightarrow$ Behavioral intention & 0.26 & $4.69^{\mathrm{a}}$ & Supported \\
H6-Satisfaction $\rightarrow$ Behavioral intention & 0.41 & $6.62^{\mathrm{a}}$ & Supported \\
\hline
\end{tabular}

${ }^{\mathrm{a}} \mathrm{p}<0.001,{ }^{\mathrm{b}}$ not significant/

Note: 5,000 samples bootstrapping procedure used

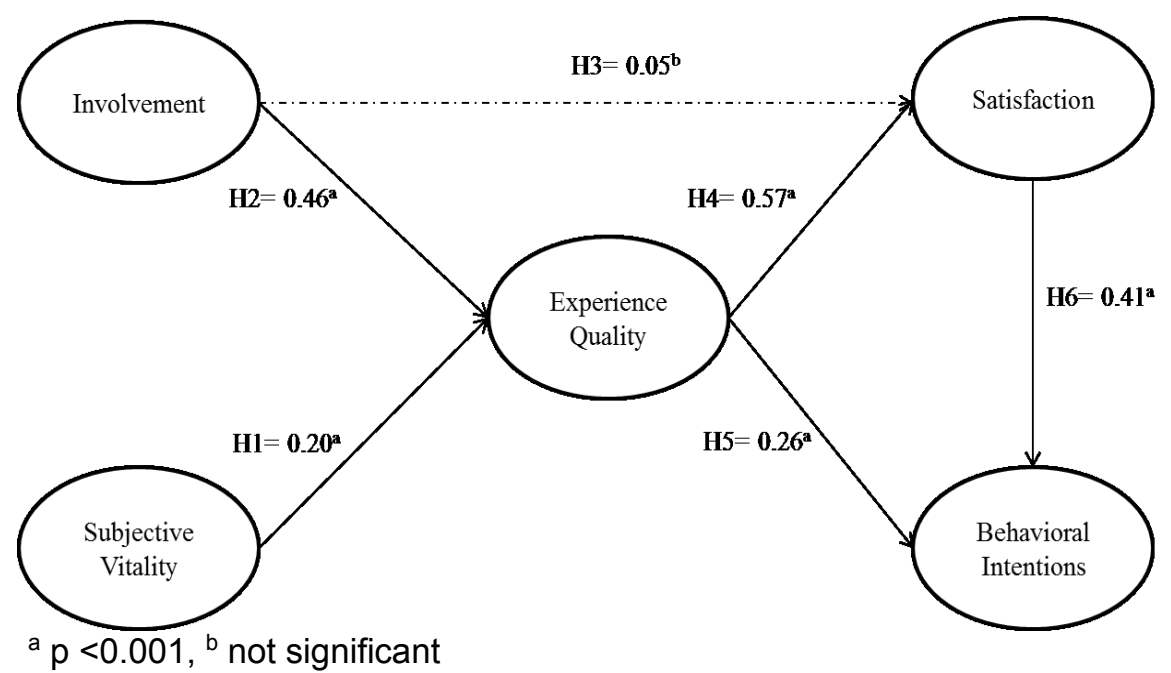

Figure 2. Estimated Results of the Model 
The roles of subjective vitality, involvement, experience quality, and satisfaction in tourists' behavioral intentions.

asserted that experience quality has a mediating role between involvement and satisfaction. This is consistent with previous studies that handle experience quality as a mediator (Altunel \& Erkut 2015; Liu, Horng, \& Chou, 2015). Additionally, a number of prior studies have investigated the relationship between involvement and satisfaction. For example, Chiu et al. (2014) and Prayag and Ryan (2012) found no significant relationship. In contrast, Hwang et al. (2005) proposed and found a causal relationship.

This study demonstrated that there is a positive and significant effect of experience quality on satisfaction. These results are consistent with past studies (Altunel, \& Erkut 2015; Chen \& Chen, 2010; Jin, Lee, \& Lee, 2015; Martin-Ruiz et al., 2010). Consistent with previous studies, experience quality has a positive effect on behavioral intentions including the intention to recommend (Altunel, \& Erkut 2015; Liu et al., 2015; Martin-Ruiz et al., 2010). Additionally, a direct link between tourists' satisfaction and their behavioral intentions is indicated, similar to other studies (Akhoondnejad, 2016; Hutchinson, Lai, \& Wang, 2009; Prayag, Hosany, \& Odeh, 2013; Zabkar, Brencic, \& Dmitrovic, 2010).

\section{Managerial implications}

The major finding of this study reveals that vitality has a positive effect on experience quality and this significant relationship presents some managerial implications for the tourism industry. These implications can be framed in terms of travel agencies/tour guides and cultural site managers.

Tourism agencies and tour guides should take tourists energies and attention levels into consideration and should plan the travel roots, vehicles, lunch \& dining activities well in order to maintain tourists' vitality levels high. Because all these factors impact tourists energy levels, aliveness and enthusiasm. For site managers, it is also important to keep tourists attentions on cultural objects and provide a safe place for visitors in which they would not have problems. It is important that visitors focus on cultural elements and keeping safe themselves from other disturbing stimulants. Site managers may use gamification concept to attract and keep their attentions on the site.

Additionally, it is known that energetic people's behaviors are contagious to others and thereby increase the productivity of others (Bakker, Demerouti, \& Schaufeli, 2005). Of course, having high energy and energizing others are different concepts but having high energy may be a requirement for energizing others (Schippers \& Hogenes, 2011). Therefore, identifying these vital tourists and serving them in a special manner may be important for two reasons. First, the experience quality felt by such individuals may significantly affect the experience of others in the same group. Second, vital tourists (maybe opinion leaders) are more likely to recommend their experiences to their social environment (network).

To distinguish these individuals from others, the behavioral indicators listed below can be useful for tour guides and site managers. People with feelings of vitality tend to:

- Engage in more social interactions than others,

- Get in contact faster,

- Express less fatigue,

- Get involved in activities via asking questions and seeking more information,

- Participate in extra activities apart from tours or groups.

Finally, the link between satisfaction and behavioral intentions is crucial for travel agencies/tour guides and cultural site managers. Satisfaction of visitors is essential for re-visit and recommendation intentions which both of them are significantly important for a company's survival. Hence, it is reasonable for managers to focus on the antecedents of satisfaction. Involvement and experience quality are important factors in the formation of satisfaction. However, it should be noted that involvement with cultural tourism is not sufficient for satisfaction. A cultural site or destination should first increase the experience quality of visitors. In a similar study, Altunel and Erkut (2015) found a direct link between involvement and satisfaction. However this effect was relatively weak in comparison with the involvement-experience quality and experience quality-satisfaction relationships. As 
a result, experience quality's mediation role between involvement and satisfaction represent why experience quality of visitors is critical in satisfaction process and this finding should be taken in consideration by site managers.

\section{Recommendations for further research}

Age and generational differences may play an important role in the mediating effect of experience quality as older generations place more importance on the quality concept than younger generations (Coleman, Hladikova, \& Savelyeva, 2006; Proudfoot, 2009). Hence, it is essential for a senior tourist to have a quality experience to be satisfied with the tourism product. Younger adults are more likely to create satisfaction internally such that the balance between the environment (supply) and intrinsic motivation is skewed toward intrinsic. Age differences role in this mediation effect should be analyzed in further researches.

\section{Limitations of the study}

In the measurement of vitality scale, 3 items are deleted due to the low t-value and standardized loadings. This situation may be a sign of the scale reliability problem. However, in the reliability analysis it is seen that Cronbach alfa's of the scale is increasing when these items are deleted. Therefore, it is assumed that there is no problem of reliability in the scale of vitality.

\section{References}

Akhoondnejad, A. (2016). Tourist loyalty to a local cultural event: The case of Turkmen handicrafts festival. Tourism Management, 52, 468-477.

Akin, A. (2012). The relationships between internet addiction, subjective vitality, and subjective happiness. CyberPsychology, Behavior, and Social Networking, 15(8), 404 $-410$.

Alegre, J., \& Garau, J. (2010). Tourist satisfaction and dissatisfaction. Annals of Tourism Research, 37(1), 52-73.

Altunel, M. C., \& Erkut, B. (2015). Cultural tourism in Istanbul: The mediation effect of tourist experience and satisfaction on the relationship between involvement and recommendation intention. Journal of
Destination Marketing \& Management, 4(4), 213-221

Anderson, E. W., \& Fornell, C. (1994). A customer satisfaction research prospectus. Service quality: New Directions in Theory and Practice, 14(1), 239-266.

Anderson, E. W., Fornell, C., \& Lehmann, D. R. (1994). Customer satisfaction, market share, and profitability: Findings from Sweden. The Journal of Marketing, 58(3), 53-66.

Arkes, H. R., Herren, L. T., \& Isen, A. M. (1988). The role of potential loss in the influence of affect on risk-taking behavior. Organizational Behavior and Human Decision Processes, 42(2), 181-193.

Ash, I. E. (1913). What Makes a People Lethargic or Energetic? The American Journal of Sociology, 19(3), 370-379.

Baker, D. A., \& Crompton, J. L. (2000). Quality, satisfaction and behavioral intentions. Annals of Tourism Research 27(3), 785-804.

Bakker, A. B., Demerouti, E., \& Schaufeli, W. B. (2005). The crossover of burnout and work engagement among working couples. Human Relations, 58(5), 661-689.

Barsade, S. G. (2002). The ripple effect: Emotional contagion and its influence on group behavior. Administrative Science Quarterly, 47(4), 644-675.

Bartel, C. A., \& Saavedra, R. (2000). The collective construction of work group moods. Administrative Science Quarterly, 45(2), 197-231.

Bontis, N. (1998). Intellectual capital: an exploratory study that develops measures and models. Management Decision, 36(2), 63-76.

Brooker, E., \& Joppe, M. (2013). Trends in camping and outdoor hospitality-An international review. Journal of Outdoor Recreation and Tourism, 3, 1-6.

Brown, K. W., \& Ryan, R. M. (2004). Perils and promise in defining and measuring mindfulness: Observations from experience. Clinical Psychology: Science and Practice, 11(3), 242-248.

Carr, N. (2002a). Defining young tourists visiting beach-oriented resorts: a behavioural analysis. Anatolia, 13(1), 49-61. 
The roles of subjective vitality, involvement, experience quality, and satisfaction in tourists' behavioral intentions.

Carr, N. (2002b). The tourism-leisure behavioural continuum. Annals of Tourism Research, 29(4), 972-986.

Chang, T. Y., \& Horng, S. C. (2010). Conceptualizing and measuring experience quality: the customer's perspective. The Service Industries Journal, 30(14), 24012419.

Chen, C. C., Huang, W. J., \& Petrick, J. F. (2016). Holiday recovery experiences, tourism satisfaction and life satisfaction-Is there a relationship? Tourism Management, 53, 140-147.

Chen, C. F., \& Chen, F. S. (2010). Experience quality, perceived value, satisfaction and behavioral intentions for heritage tourists. Tourism Management, 31(1), 29-35.

Chen, Y., Lehto, X. Y., \& Cai, L. (2013). Vacation and well-being: a study of Chinese tourists. Annals of Tourism Research, 42, 284-310.

Chi, C. G. Q., \& Qu, H. (2008). Examining the structural relationships of destination image, tourist satisfaction and destination loyalty: An integrated approach. Tourism Management, 29(4), 624-636.

Chin, W. W. (1998). The partial least squares approach to structural equation modeling. Modern Methods for Business Research, 295(2), 295-336.

Chin, W. W., Gopal, A., \& Salisbury, W. D. (1997). Advancing the theory of adaptive structuration: The development of a scale to measure faithfulness

appropriation. Information

Research, 8(4), 342-367.

Chiu, Y. T. H., Lee, W. I., \& Chen, T. H. (2014). Environmentally responsible behavior in ecotourism: Antecedents and implications. Tourism Management, 40, 321-329.

Christianson, M., Spreitzer, G., Sutcliffe, K., \& Grant, A. (2005). An empirical examination of thriving at work. In National Acad. Management Meeting.

Cole, S. T., \& Scott, D. (2004). Examining the mediating role of experience quality in a model of tourist experiences. Journal of Travel \& Tourism Marketing, 16(1), 79-90.

Coleman, L. J., Hladikova, M., \& Savelyeva, M. (2006). The baby boomer market. Journal of Targeting, Measurement and Analysis for Marketing, 14(3), 191-209.
Collins, R. (1993). Emotional energy as the common denominator of rational action. Rationality and Society, 5(2), 203-230.

Cross, R., Baker, W., \& Parker, A. (2003). What creates energy in organizations? MIT Sloan Management Review, 44(4), 51-56.

Cross, R., \& Parker, A. (2004). Charged up: Creating energy in organizations. Journal of Organizational Excellence, 23(4), 3-14.

Devesa, M., Laguna, M., \& Palacios, A. (2010). The role of motivation in visitor satisfaction: Empirical evidence in rural tourism. Tourism Management, 31(4), 547-552.

Dick, A. S., \& Basu, K. (1994). Customer loyalty: toward an integrated conceptual framework. Journal of the Academy of Marketing Science, 22(2), 99-113.

Dolnicar, S., Yanamandram, V., \& Cliff, K. (2012). The contribution of vacations to quality of life. Annals of Tourism Research, 39(1), 59-83.

Eid, R., \& El-Gohary, H. (2015). The role of Islamic religiosity on the relationship between perceived value and tourist satisfaction. Tourism Management, 46, 477-488.

Ekinci, Y., Dawes, P. L., \& Massey, G. R. (2008). An extended model of the antecedents and consequences of consumer satisfaction for hospitality services. European Journal of Marketing, 42(1/2), 35-68.

Fick, G. R., \& Ritchie, J. B. (1991). Measuring service quality in the travel and tourism industry. Journal of Travel Research, 30(2), 2-9.

Fini, A. E. S., Kavousian, J., Beigy, A., \& Emami, M. (2010). Subjective vitality and its anticipating variables on students. Procedia Social and Behavioral Science, 5, 150-156.

Fornell, C., \& Larcker, D. F. (1981). Evaluating structural equation models with unobservable variables and measurement error. Journal of Marketing Research, 18(1), $39-50$.

Fredrickson, B. L. (2003). The value of positive emotions: The emerging science of positive psychology is coming to understand why it's good to feel good. American Scientist, 91(4), 330-335.

Gallarza, M. G., \& Saura, I. G. (2006). Value dimensions, perceived value, satisfaction and loyalty: an investigation of university 
students' travel behaviour. Tourism Management, 27(3), 437-452.

Gentile, C., Spiller, N., \& Noci, G. (2007). How to sustain the customer experience: An overview of experience components that cocreate value with the customer. European Management Journal, 25(5), 395-410.

Gilbert, D., \& Abdullah, J. (2004). Holiday taking and the sense of well-being. Annals of Tourism Research, 31(1), 103-121.

Goldsmith, R. E., \& Emmert, J. (1991). Measuring product category involvement: a multitrait-multimethod study. Journal of Business Research, 23(4), 363-371.

Gursoy, D., \& Gavcar, E. (2003). International leisure tourists' involvement profile. Annals of Tourism Research, 30(4), 906-926.

Hair Jr, J. F., Hult, G. T. M., Ringle, C., \& Sarstedt, M. (2013). A primer on partial least squares structural equation modeling (PLSSEM). Los Angeles: Sage Publications.

Havitz, M. E., \& Dimanche, F. (1999). Leisure involvement revisited: Drive properties and paradoxes. Journal of Leisure Research, 31(2), 122.

Henseler, J., Ringle, C. M., \& Sinkovics, R. R. (2009). The use of partial least squares path modeling in international marketing. Advances in International Marketing (AIM), 20, 277-320.

Hernández-Lobato, L., Solis-Radilla, M. M., Moliner-Tena, M. A., \& Sánchez-García, J. (2006). Tourism destination image, satisfaction and loyalty: a study in IxtapaZihuatanejo, Mexico. Tourism Geographies, 8(4), 343-358.

Hobfoll, S. E., Johnson, R. J., Ennis, N., \& Jackson, A. P. (2003). Resource loss, resource gain, and emotional outcomes among inner city women. Journal of Personality and Social Psychology, 84(3), 632.

Hochgraefe, C., Faulk, S., \& Vieregge, M. (2012). Links between Swiss hotel guests' product involvement and brand loyalty. Journal of Hospitality Marketing \& Management, 21(1), 20-39.

Hsu, C. H., Cai, L. A., \& Wong, K. K. (2007). A model of senior tourism motivationsAnecdotes from Beijing and Shanghai. Tourism Management, 28(5), 1262-1273.

Hui, T. K., Wan, D., \& Hsuan-Yi Cheng, H. Y. (2010). Case study of tourist revisit behaviour in Singapore. Advances in Hospitality and Leisure, 6, 27-42.

Hutchinson, J., Lai, F., \& Wang, Y. (2009). Understanding the relationships of quality, value, equity, satisfaction, and behavioral intentions among golf travelers. Tourism Management, 30(2), 298-308.

Hwang, S. N., Lee, C., \& Chen, H. J. (2005). The relationship among tourists' involvement, place attachment and interpretation satisfaction in Taiwan's national parks. Tourism Management, 26(2), 143-156.

Jin, N. P., Lee, S., \& Lee, H. (2015). The effect of experience quality on perceived value, satisfaction, image and behavioral intention of water park patrons: new versus repeat visitors. International Journal of Tourism Research, 17(1), 82-95.

Josiam, B. M., Smeaton, G., \& Clements, C. J. (1999). Involvement: Travel motivation and destination selection. Journal of Vacation Marketing, 5(2), 167-175.

Jung, C. G. (1960). On the nature of the psyche (R.G.C.Hull Trans.) Princeton: Princeton University Press.

Kang, M., \& Gretzel, U. (2012). Effects of podcast tours on tourist experiences in a national park. Tourism Management, 33(2), 440-455.

Kao, Y. F., Huang, L. S., \& Wu, C. H. (2008). Effects of theatrical elements on experiential quality and loyalty intentions for theme parks. Asia Pacific Journal of Tourism Research, 13(2), 163-174.

Kim, D. J. (2012). An investigation of the effect of online consumer trust on expectation, satisfaction, and postexpectation. Information Systems and EBusiness Management, 10(2), 219-240.

Kim, H., Woo, E., \& Uysal, M. (2015). Tourism experience and quality of life among elderly tourists. Tourism Management, 46, 465476.

Klaus, P., \& Maklan, S. (2012). EXQ: a multiple-item scale for assessing service experience. Journal of Service Management, 23(1), 5-33.

Laurent, G., \& Kapferer, J. N. (1985). Measuring consumer involvement profiles. Journal of Marketing Research, 22(1), 41-53. 
The roles of subjective vitality, involvement, experience quality, and satisfaction in tourists' behavioral intentions.

Lee, J., \& Beeler, C. (2006). The relationships among quality, satisfaction, and future intention for first-time and repeat visitors in a festival setting. Event Management, 10(4), 197-208.

Lee, J., Graefe, A. R., \& Burns, R. C. (2007). Examining the antecedents of destination loyalty in a forest setting. Leisure Sciences, 29(5), 463-481.

Li, X., Li, X. R., \& Hudson, S. (2013). The application of generational theory to tourism consumer behavior: An American perspective. Tourism Management, 37, 147-164.

Lifton, R. J. (1976). The life of the self: Toward a new psychology. New York: Simon \& Schuster.

Liu, C. H. S., Horng, J. S., \& Chou, S. F. (2015). A critical evaluation of sustainable tourism from the integrated perspective: Conducting moderated-mediation analysis. Tourism Management Perspectives, 16, 43-50.

Lo, A. S., \& Lee, C. Y. (2011). Motivations and perceived value of volunteer tourists from Hong Kong. Tourism Management, 32(2), 326-334.

Lu, L., Chi, C. G., \& Liu, Y. (2015). Authenticity, involvement, and image: Evaluating tourist experiences at historic districts. Tourism Management, 50, 85-96.

Machleit, K. A., \& Mantel, S. P. (2001). Emotional response and shopping satisfaction: moderating effects of shopper attributions. Journal of Business Research, 54(2), 97-106.

Manfredo, M. J. (1989). An investigation of the basis for external information search in recreation and tourism. Leisure Sciences, 11(1), 29-45.

Martín-Ruiz, D., Castellanos-Verdugo, M., \& de los Ángeles Oviedo-García, M. (2010). A visitors' evaluation index for a visit to an archaeological

Management, 31(5), 590-596.

McCabe, S., \& Johnson, S. (2013). The happiness factor in tourism: Subjective wellbeing and social tourism. Annals of Tourism Research, 41, 42-65.

McDowall, S. (2010). International tourist satisfaction and destination loyalty: Bangkok, Thailand. Asia Pacific Journal of Tourism Research, 15(1), 21-42.
McNair, D., Lorr, M., \& Droppleman, L. (1971). Profile of Mood States. San Diego: Ed ITS/Educational and Industrial Testing Service.

Miller, J. B., \& Stiver, I. P. (1997). The healing connection. Boston: Beacon Press.

Nam, J., Ekinci, Y., \& Whyatt, G. (2011). Brand equity, brand loyalty and consumer satisfaction. Annals of Tourism Research, 38(3), 1009-1030.

Nix, G. A., Ryan, R. M., Manly, J. B., \& Deci, E. L. (1999). Revitalization through selfregulation: The effects of autonomous and controlled motivation on happiness and vitality. Journal of Experimental Social Psychology, 35(3), 266-284.

Nunnally, J. C., \& Bernstein, I. H. (1994). The assessment of reliability. Psychometric Theory, 3, 248-292.

Oliver, R. L. (1997). Satisfaction: A Behavioral Perspective on the Consumer. New York: Irwin/McGraw-Hill.

Oliver, R. L. (1999). Whence consumer loyalty? The Journal of Marketing, 63, 3344.

Oppermann, M. (2000). Tourism destination loyalty. Journal of Travel Research, 39(1), 78-84.

Ortner, C. N., Kilner, S. J., \& Zelazo, P. D. (2007). Mindfulness meditation and reduced emotional interference on a cognitive task. Motivation and emotion, 31(4), 271283.

Otto, J. E., \& Ritchie, J. B. (1996). The service experience in tourism. Tourism Management, 17(3), 165-174.

Parasuraman, A., Zeithaml, V. A., \& Malhotra A. (2005). ES-QUAL a multiple-item scale for assessing electronic service quality. Journal of Service Researc, $h$ 7(3), 213-233.

Pendergast, D. (2010). Getting to Know the $Y$ Generation. In Benckendorff, P., Moscardo, G., \& Pendergast, D. (Eds.), Tourism and Generation Y (pp. 1-15). Cambridge: CAB International

Penninx, B. W., Guralnik, J. M., Bandeen-Roche, K., Kasper, J. D., Simonsick, E. M., Ferrucci, L., \& Fried, L. P. (2000). The protective effect of emotional vitality on adverse health outcomes in disabled older women. Journal of the 
American Geriatrics Society, 48(11), 13591366.

Perls, F. (1973). The Gestalt approach \& eye witness to therapy. Science \& Behavior Books.

Petrick, J. F. (2004). The roles of quality, value, and satisfaction in predicting cruise passengers' behavioral intentions. Journal of Travel Research, 42(4), 397-407.

Petrick, J. F., \& Backman, S. J. (2002). An examination of the determinants of golf travelers' satisfaction. Journal of Travel Research, 40(3), 252-258.

Peterson, C., \& Seligman, M. E. (2004). Character strengths and virtues: $A$ handbook and classification. New York: Oxford University Press.

Prayag, G. (2009). Tourists' evaluations Of Destınatıon Image, Satısfactıon, And Future Behavioral Intentions - The Case of Mauritius. Journal of Travel \& Tourism Marketing, 26(8), 836-853.

Prayag, G., Hosany, S., \& Odeh, K. (2013). The role of tourists' emotional experiences and satisfaction in understanding behavioral intentions. Journal of Destination Marketing \& Management, 2(2), 118-127.

Prayag, G., \& Ryan, C. (2012). Antecedents of tourists' loyalty to Mauritius The role and influence of destination image, place attachment, personal involvement, and satisfaction. Journal of Travel Research, 51(3), 342-356.

Prebensen, N., Skallerud, K., \& Chen, J. S. (2010). Tourist motivation with sun and sand destinations: satisfaction and the womeffect. Journal of Travel \& Tourism Marketing, 27(8), 858-873.

Proudfoot, S. (2009). Aging boomers picky travelers. Canada.com, Retrieved from. http://www.canada.com 03.30.09.

Quinn, R. W. (2007). Energizing others in work connections. In J. E. Dutton, \& B. R. Ragins (Eds.), Exploring positive relationships at work: Building a theoretical and research foundation (pp. 73-90). Mahwah: Lawrence Erlbaum.

Reid, I. S., \& Crompton, J. L. (1993). A taxonomy of leisure purchase decision paradigms based on level of involvement. Journal of Leisure Research, 25(2), 182-202.
Reisinger, Y., \& Turner, L. W. (2003). Crosscultural behaviour in tourism: Concepts and analysis. Oxford: Butterworth-Heinemann.

Rigdon, E. E. (2005). Structural equation modeling: nontraditional alternatives. Wiley StatsRef: Statistics Reference Online, 1-12.

Ringle, C. M., Wende, S., \& Becker, J.-M. (2015). Smartpls 3. Boenningstedt: SmartPLS. http://www.smartpls.com 10.11.2016.

Rittichainuwat, B. N., Qu, H., \& Mongknonvanit, C. (2002). A study of the impact of travel satisfaction on the likelihood of travelers to revisit Thailand. Journal of Travel \& Tourism Marketing, 12(2-3), 19-43.

Rothschild, M. L. (1984). Perspectives on involvement: current problems and future directions. Advances in Consumer Research, 11(1), 216-217.

Rozanski, A., Blumenthal, J. A., Davidson, K. W., Saab, P. G., \& Kubzansky, L. (2005). The epidemiology, pathophysiology, and management of psychosocial risk factors in cardiac practice: the emerging field of behavioral cardiology. Journal of the American College of Cardiology, 45(5), 637-651.

Ryan, R. M., \& Bernstein, J. H. (2004). Vitality. In C. Peterson, \& M. E. P. Seligman (Eds.), Character strengths and virtues: $A$ handbook and classification (pp. 273-290). New York: Oxford University Press.

Ryan, R. M., \& Deci, E. L. (2001). On happiness and human potentials: A review of research on hedonic and eudaimonic well-being. Annual Review of Psychology, 52(1), 141-166.

Ryan, R. M., \& Frederick, C. (1997). On energy, personality, and health: Subjective vitality as a dynamic reflection of well-being. Journal of Personality, 65(3), 529-565.

Salama-Younes, M. (2011). Positive mental health, subjective vitality and satisfaction with life for French physical education students. World Journal of Sport Sciences, 4(2), 90-97.

Schippers, M. C., \& Hogenes, R. (2011). Energy management of people in organizations: A review and research agenda. Journal of Business and Psychology, 26(2), 193-203. 
The roles of subjective vitality, involvement, experience quality, and satisfaction in tourists' behavioral intentions.

Seaborn, K., \& Fels, D. I. (2015). Gamification in theory and action: A survey. International Journal of Human-Computer Studies, 74, 14-31.

Selin, S. W., \& Howard, D. R. (1988). Ego involvement and leisure behavior: A conceptual specification. Journal of Leisure Research, 20(3), 237-244.

Shirom, A. (2003). Feeling vigorous at work? The construct of vigor and the study of positive affect in organizations. Research in organizational stress and well-being, 3, 135-165.

Sirakaya, E., Petrick, J., \& Choi, H. S. (2004). The role of mood on tourism product evaluations. Annals of Tourism Research, 31(3), 517-539.

Sirgy, M. J., Kruger, P. S., Lee, D. J., \& Grace, B. Y. (2011). How does a travel trip affect tourists' life satisfaction? Journal of Travel Research, 50(3), 261-275.

Stewart, A., Hays, R. D., \& Ware, J. E. (1992). Health perceptions, energy/fatigue, and health distress measures. Duke University Press.

Strauss,W., \& Howe, N. (1997). The fourth turning: An American Prophecy. New York: Broadway Books.

Su, L., Swanson, S. R., \& Chen, X. (2016). The effects of perceived service quality on repurchase intentions and subjective wellbeing of Chinese tourists: The mediating role of relationship quality. Tourism Management, 52, 82-95.

Sugerman, D. (2003). Motivation of older adults to participate in outdoor adventure programs. The Journal of Experiential Education, 25(3), 346.

Sun, X., Chi, C. G. Q., \& Xu, H. (2013). Developing destination loyalty: the case of Hainan Island. Annals of Tourism Research, 43, 547-577.

Thayer, R. E. (1987). Energy, Tiredness and Tension Effects of a Sugar Snack vs. Moderate Exercise. Journal of Personality and Social Psychology, 52, 119-125.

Thayer, R. E. (1996). The origin of everyday moods: Managing energy, tension, and stress. New York: Oxford University Press.

Tonguç, S. E., \& Yale P. (2010). İstanbul Hakkında Her Şey. İstanbul: Boyut Yayıncılık.
Totterdell, P. (2000). Catching moods and hitting runs: mood linkage and subjective performance in professional sport teams. Journal of Applied Psychology, 85(6), 848.

Uncles, M. D., Dowling, G. R., \& Hammond, K. (2003). Customer loyalty and customer loyalty programs. Journal of Consumer Marketing, 20(4), 294-316.

Uysal, R., Satici, S. A., \& Akin, A. (2013).

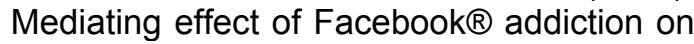
the relationship between subjective vitality and subjective happiness. Psychological reports, 113(3), 948-953.

Uysal, M., Sirgy, M. J., Woo, E., \& Kim, H. L. (2015). Quality of life (QOL) and well-being research in tourism. Tourism Management, 53, 244-261.

Vargo, S. L., \& Lusch, R. F. (2004). Evolving to a new dominant logic for marketing. Journal of Marketing, 68(1), 1-17.

Vinzi, V. E., Chin, W. W., Henseler, J., Wang, H. (2010) Editorial: Perspectives on partial least squares. In: Vinzi, V. E., Chin, W. W., Henseler, J., Wang, H. (eds.) Handbook of Partial Least Squares: Concepts, Methods and Applications, 1-20. Heidelberg: Springer-Verlag.

Wang, C. Y., \& Hsu, M. K. (2010). The relationships of destination image, satisfaction, and behavioral intentions: An integrated model. Journal of Travel \& Tourism Marketing, 27(8), 829-843.

Watson, D., \& Tellegen, A. (1985). Toward a consensual structure of mood. Psychological Bulletin, 98, 219-235.

Werts, C. E., Linn, R. L., \& Jöreskog, K. G. (1974). Intraclass reliability estimates: Testing structural assumptions. Educational and Psychological Measurement, 34(1), 2533.

Williams, P., \& Soutar, G. N. (2009). Value, satisfaction and behavioral intentions in an adventure tourism context. Annals of Tourism Research, 36(3), 413-438.

Wirtz, J. (2003). Halo in customer satisfaction measures: The role of purpose of rating, number of attributes and customer involvement. International Journal of Service Industry Management, 14(1), 96-119.

Wixom, B. H., \& Watson, H. J. (2001). An empirical investigation of the factors 
affecting data warehousing success. MIS Quarterly, 25(1), 17-41.

Yenen, Ş. (2013). İstanbul: Quick Guide. İstanbul: Yenen Travel Publishing.

Yoon, Y., \& Uysal, M. (2005). An examination of the effects of motivation and satisfaction on destination loyalty: a structural model. Tourism Management, 26(1), 45-56.

YPartnership and Harrison Group (2010). 2010 portrait of American travelers. Kansas City: The YPartnership.

Yuksel, A. (2008). Tourist Satisfaction and Complaining Behavior: Measurement and Management Issues in the Tourism and Hospitality Industry. New York: Nova Science Publishers.

Žabkar, V., Brenčič, M. M., \& Dmitrović, T. (2010). Modelling perceived quality, visitor satisfaction and behavioural intentions at the destination level. Tourism Management, 31(4), 537-546.
Zaichkowsky, J. L. (1985). Measuring the involvement construct. Journal of Consumer Research, 12(3), 341-352.

Zaichkowsky, J. L. (1994). The personal involvement inventory: Reduction, revision, and application to advertising. Journal of Advertising, 23(4), 59-70.

Zeithaml, V. A., Berry, L. L., \& Parasuraman, A. (1996). The behavioral consequences of service quality. The Journal of Marketing, 60(2), 31-46.

Zeithaml, V.A., Bitner, M. J., \& Gremler, D.D. (2013). Services Marketing: integrating customer focus across the firm. (6th ed.) New York: McGraw-Hill, Inc.

Zins, A. H. (2002). Consumption emotions, experience quality and satisfaction: a structural analysis for complainers versus non-complainers. Journal of Travel \& Tourism Marketing, 12(2-3), 3-18. 